\title{
ВІЗІЯ ТВОРЧОСТІ РОМАНА КУПЧИНСЬКОГО В ЛІТЕРАТУРНО-КРИТИЧНІЙ ДУМЦІ
}

\author{
МАРТА МЕЛЬНИК \\ Львівський державний університет внутрішніх справ, Львів — Україна \\ WIZJA TWÓRCZOŚCI ROMANA KUPCZYŃSKIEGO
W ASPEKCIE LITERACKO-KRYTYCZNYM
}

MARTA MELNYK

Lwowski Państwowy Uniwersytet Spraw Wewnętrznych, Lwów — Ukraina

STRESZCZENIE. Artykuł stanowi próbę analizy twórczości Romana Kupczyńskiego, żołnierza Ukraińskiej Dywizji Strzelców Siczowych, kompozytora, barda, poety, prozaika, dramaturga, publicysty i felietonisty $\mathrm{w}$ oparciu o prace przedwojennych i współczesnych literaturoznawców. Podjęta została również próba systematycznego ujęcia twórczości pisarza, różnorodnej palety jego talentów, dojrzewającej na frontach I wojny światowej, w okresie międzywojennym we Lwowie oraz na emigracji.

\section{VISION OF ROMAN KUPCHYNSKYI'S CREATIVE WORK IN THE LITERARY-CRITIC OPINION}

\author{
MARTA MEL'NYK \\ Lviv State University of Inner Affairs, Lviv - Ukraine
}

ABSRACT. The article is dedicated to the creative work of R. Kupchynskyi, the soldier of Ukrainian Sich, a composer, a poet, a prose writer, a playwright, a publicist, reflected in the works of pre-war and modern literature experts. An attempt to analyze the creative work of the writer, his talent that was formed during World War I and the period between the wars in L'viv and in emigration has been made.

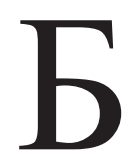

агатолітню „неприсутність” Р. Купчинського в офіційному просторі української літератури та науки радянського періоду підтверджує відсутність праць, що інформували б про увагу до його творчої постаті в ділянках книговидання, бібліографії й літературної критики. Якщо зважати на появу імені письменника в науковому дискурсі літературознавчої та історичної наукових галузей з 1989 року в Україні у зв’ язку із ,реставрацією” насамперед історії ЗУНР, УГА, стан дослідження теми залишається недостатнім.

На відміну від своїх побратимів, колишніх українських січових стрільців Ю. Шкрумеляка, В. Бобинського, творчість яких навіть у радянський час користувалася увагою дослідників чи видавців, твори Р. Купчинського залишаються досі невідомими широкому загалу читачів. Перша відома нам публікація Р. Купчинського датована 1915 роком і опублікована в газеті „Вісник Союза Визволення України" (Відень) під псевдонімом Стрілець Р. К. Назва Нова пісня Українських січових стрільців символічно розпочинала на шпальтах цього часопису традицію публікувати інші поетичні твори на стрілецьку тематику. Автор репрезентував себе насамперед як співець стрілецької теми в літературі, утверджуючи й надалі власне реноме нарисами, авторською поезією, пісенною ліри- 
кою, оповіданнями, мемуарами у львівських часописах і стрілецькій періодиці. Жодної поетичної збірки Р. Купчинський друком не видав.

Літературно-критичні відгуки, що з'являлися в галицькій періодиці воєнного і міжвоєнного часу ${ }^{1}$, відтворюють загальні риси стрілецького силуету Р. Купчинського. Деякі з авторів відгуків (Осип Назарук, Лука Луців) також перебували в лавах Українських січових стрільців, що дало їм змогу рельєфно змалювати портрет Р. Купчинського-стрільця, зокрема вже 1916 р. О. Назарук репрезентує Р. Купчинського як „молодого стрільця” та автора популярної в стрілецькому середовищі сатиричної поеми Новініяда (1915). Згодом 1918 р. вже під псевдонімом Козак Нитка в нарисі Преса Украӥнського січового війська він посилить свої суперлятиви щодо поеми, мотивуючи їі появу потребою психологічного та емоційного релаксу вояків-усусусів ${ }^{2}$. Вже після війни в рецензії, що вийшла в журналі „Дзвони”, історик Володимир Заїкин зауважив розмаїття творчого таланту Р. Купчинського. Він чи не вперше оцінив їх як рівновеликі, схарактеризувавши автора як знаменитого гумориста, доброго лірика й епіка. У той же час відомий літературознавець Свген Пеленський (1908-1956) називає Р. Купчинського „головним представником групи галицьких поетів національної тематики"з.

У міжвоєнний період спостерігаємо діаметрально протилежні оцінки Р. Купчинського-митця, що звучать полемічно: як про оригінального, модерного поета, або як про другорядного автора із когорти колишніх січових стрільців. Найбільшим апологетом першої групи критиків був Богдан Лепкий, який в огляді Наме письменство 4 оцінював поезію Р. Купчинського з огляду на іii модерність, рафінованість манери поетичного вислову, що, за його словами, „витончена за формою традиційного класичного і модерного вірша"5. В Історії української культури (1936-1937) відомий педагог і дослідник новочасної української літератури Володимир Радзикевич (1986-1966) зауважив, що на полі стрілецької пісенної творчості вибився в першу чергу Р. Купчинський і Л. Лепкий. Він же стверджує, що епічна творчість Р. Купчинського не могла затьмарити його великих заслуг як творця стрілецької пісні. Він зазначає, що поет був останнім стрільцем-романтиком, який внаслідок відповідних обставин не мав можливості написати велику епопею УСС і наших визвольних змагань.

31939 р., як відзначають дослідники стрілецької пісні, центром видавничої та дослідницької діяльності у справі стрілецької історії та творчості стають США, куди з Галичини змушені були емігрувати стрілецькі барди, учасники січово-стрілецького чину. Саме там, у діаспорі, вийшли друком поема Р. Купчинського Скоропад (1965), антологія авторських пісень Ми йдемо в бій (1977), вибране Невиспівані пісні (1983).

Окремо добірка віршів із коментарями ввійшла до антологій сучасної поезії Координати (1969) та Слово (1978). Ці видання актуалізували інтерес до постаті Р. Купчинського в текстологічному аспекті. У коментарях до цих видань упорядники роблять спробу сформулювати психологічні особливості

\footnotetext{
${ }^{1}$ О. Назарук, Слідами Українських Січових Стрільиів, Львів 1916, с. 64

${ }^{2}$ Козак Нитка, Преса УкР. Січового війська, 1918, с. 7.

${ }^{3}$ С. Ю. Пеленський, Українські поети 20-х років. Антологія сучасної української поезії, Львів 1936, с. 81.

${ }^{4}$ Цит. за: Т. Сал ига, Bid „, Молодої Музи” до символізму та інших напрямків, [в:] „Українське літературознавство", вип. 57, Львів 1993, с. 36.

${ }^{5}$ Там само, с. 36.
} 
митця. До прикладу, Іван Рудницький пише: „Р. Купчинський відзначається великим природнім гумором і даром оповідання. Звик ділити людей на ,інтелігентних” та „неінтелігентних інтелігентів” - і подає собою зразковий приклад „,інтелегентного інтелігента". Має водночас тонке відчуття для справ одиничної і громадської етики"“. Очевидно, ці спостереження позбавлені шаблонності, якою рясніли літературні хрестоматії, що виходили в той час у підрадянській Україні.

Погляди критиків діаспори на творчу й людську сутність Р. Купчинського, без сумніву, є цінними для подальшої дослідницької роботи над творчістю Р. Купчинського, який водночас був сином греко-католицького священика і вояком по духу. Імператив галицького середовища, родинного світу, його навчання в університетах, життєвий вибір детермінували координати естетичного руху Р. Купчинського-митця.

Упорядник збірки Невиспівані пісні Богдан Бойчук схарактеризував Р. Купчинського як людину невикористаних можливостей, „нерівного творчого почерку". Він справедливо наголосив на рівновеликості усього діапазону творчих обдарувань письменника, що сприймається безумовно талановитою особистістю, особливо в процесі створення епіграм і фейлетонів. Критик пише, що „сьогодні важко судити, був той талант більший чи менший, бо автор не дозволив йому виявитися"' . Отже, бінарна опозиція реалізація / нехтування в підході до власної творчості накреслювала на обрії Р. Купчинського передусім поетичний, піснетворчий та гумористично-сатиричний напрямки.

Белетристика Р. Купчинського не дістала належної оцінки на відміну від його літературно-критичних праць 1920-1930-х років, у яких „звірялися” поезія й художня проза письменника. У статті Б. Бойчука бачимо першу спробу окреслити силует Р. Купчинського-поета через „кардіограму” динаміки поетичної продуктивності, яку автор бачить „трьома згущеними наворотами” - 1920-i, 1930-і, 1940-і рр. Водночас висновки критика про лінію „спаду” в ділянці поезії є здебільшого імпресійні, вони докладно не аргументовані, адже в їхній основі передусім суб'єктивні враження, що склалися в результаті обопільного спілкування впродовж тривалого часу. Пояснюючи творчу депресію Р. Купчинського, він логічно обгрунтовує їі етнопсихологічними критеріями, насамперед особливостями національної свідомості.

Про приналежність Р. Купчинського до гурту поетів „модерної української поезіі” було задекларовано вже в літературно-критичних працях 1960-х років (студії Яра Славутича, Юрія Шереха, М. Степняка, Г. Костюка, М. Семчишина). Юрій Шерех з'ясовує стильові пошуки літературної групи „Митуса”, до якої належав Р. Купчинський, указує на іiї символістську орієнтацію в поєднанні з передчуттям майже МУРівського пошуку джерел національного стилю. Інший ракурс у М. Семчишина, який наголосив на перспективності націологічного, етнопсихологічного наукового погляду на західноукраїнську літературу періоду від Визвольних змагань аж до початку Другої світової війни, що досі є недослідженою картиною того, „як проявляла себе українська духовність галицького П'ємонту в літературі і що вона по собі залишила"в.

Надто узагальнено схарактеризовано Р. Купчинського як поета-символіста і в антології Координати, де йдеться про стиль „народного антропоморфізму”.

${ }^{6}$ І. Кедрин, Поема, ї̈ тло і автор, [в:] Купчинський Р., Скоропад: Поема, післям. І. Кедрина, Нью-Йорк 1965, с. 8.

${ }^{7}$ Р. Купчи н ськ и й, Невиспівані пісні, [в:] його ж, Вибрана лірика і проза, Нью-Йорк 1983, с. 9.

${ }^{8}$ М. Семчишин, Тисяча років украӥнської культури, Київ 1993, с. 342.

9 Р. Купчинський Координати: Антологія сучасної украӥнської поезї̈ на Заході, упоряд. Б. Бойчук, Б. Рубчак, вст. ст. І. Фізера, Київ 1969, с. 225. 
Дискусійною вважаємо висловлену тут думку про вплив Василя Бобинського на поетичну творчість Р. Купчинського-символіста. 3 огляду на те, що ії підтримують без належного обгрунтування деякі сучасні дослідники ${ }^{10}$, вважаємо, що символістська лірика Р. Купчинського потребує відповідного типологічного зіставлення та об’єктивної оцінки по лінії „Р. Купчинський - В. Бобинський”. Загалом в коментарях до згаданої вище антології зроблено спробу оцінити естетику поезій Р. Купчинського: порівнюється лірика раннього періоду „Митуси” 3 поетичними творами Другої світової війни та повоєнного часу. Критика визнає, що вони „позбавлені вільності та оригінальності, що їх бачимо в ранніх творах. Вони спокійніші, традиційніші, скромніші”. Унаслідок таких міркувань назріває думка про потребу еволюційного погляду на творчу особистість Р. Купчинського і зокрема на зміну літературних родів і видів у його творчості у зв'язку з життєвими та суспільними катаклізмами. Крім того, в згаданій антології вперше генералізується епічний вимір творчості Р. Купчинського. Висловлено спостереження про нахил його до епічних форм уже в ранній поезії. Такої думки дотримується й Ігор Соневицький, упорядник збірника $M u$ ŭдемо в бій. Иого оцінки типологічно близькі до міркувань Я. Гординського, який ще 1939 р. писав про грядуще домінування в тодішньому літературному процесі Галичини нового прозового „воєнного стилю”. Як справедливо зазначають сучасні дослідники, Я. Гординський значно переоцінив його значення.

Окреме питання історіографії лежить у площині вивчення біографії Р. Купчинського. Діаспорні публікації випрозорюють проблему іiї неповноти. У цьому ракурсі цінною є стаття часопису „Дзвін” під назвою Бард стрілецької музи, що виконана в жанрових рамках некрологу, має форму нарису, що відтворює портрет і незнані досі деталі життєпису Р. Купчинського. Біографічна лінія матиме своє продовження в наукових пошуках літературознавців незалежної України, зокрема в працях В. Качкана, М. Ільницького, І. Приходько, Л. Сироти.

В Україні відродження творчого імені письменника розпочалося 3 кінця 1980-х рр., коли з'явилися перші публікації у львівській періодиці про Р. Купчинського як поета-стрільця (Т. Салига, Р. Федорів). У публікації Р. Федоріва прозирає дух епохи перебудови, за якої можливим стало ревізувати деякі ідеологічні стереотипи-міфи радянської системи, зокрема щодо українських січових стрільців, про яких тоді „було назагал говорено як про зграю буржуазних націоналістів, які на початку першої світової війни добровільно зголосились до австрійської армії, щоб допомагати „австріякам” воювати проти братівросіян і водночас проти братів-наддніпрянців"11.

Найбільше уваги 3-посеред інших українських літературознавців особі Р. Купчинського приділив Т. Салига. Задля повернення в простір національної культури „одного із найкращих, найславніших усусусів”12 він приклав чимало зусиль, пропагуючи ім'я Поета $i$ Воїна в численних науково-популярних статтях на шпальтах періодичних видань „Просвіта”, „Дзвін”, „Україна”, „Літературна панорама”, „Друг читача”. Відтворюючи силует митця в усусівському однострої, дослідник увів у простір сучасної української літератури поетичний текст Р. Купчинського, упорядкувавши антологію Стрілецька Голгофа (1992), що, на думку критиків, стала першим букетом з незнаних і багатьма

${ }^{10}$ У. Бондарук, Бард стрілецької музи (У периі роковини смерти Романа Купчинського), [в:] Між двома світами, Донецьк 1996, с. 65.

${ }^{11}$ Р. Федорів, Чотири поета із коша січових стрільизів, [в:] „Жовтень”, 1989, № 5, с. 17.

${ }^{12}$ Т. Салига, Чи дійсність изе була... [Р. Купчинський], [в:] його ж, Імператив: (Літературознавчі статті, критика, публіциистика), Львів 1997, 324 с. 
нечуваних поетичних квітів української стрілецької поезії ${ }^{13}$. Тридцять два твори Р. Купчинського, подані на сторінках цього видання, вперше відкривали читачеві в Україні його як піснетворця, витонченого лірика, автора героїчної поезії. Оглядова стаття побудована на засадах культурно-історичної методології. У ній кожну постать і постать Р. Купчинського зокрема розглядають у системі процесу, „в тому історичному вирі, котрі цей процес формували". Відзначимо, що в дослідженнях Тараса Салиги викристалізовано основні проблемно-тематичні вузли, присутність яких прослідковуватиметься в студіях інших науковців України. Питання рейтингу творчих талантів Р. Купчинського, порушене у працях критики української діаспори, переростає в студіях Т. Салиги в проблему родового пріоритету в генологічній свідомості Р. Купчинського. Він є прихильником точки зору про ліризм як першоелемент творчого обдарування Р. Купчинського. У статті Гей, Січ іде, красен мак извіте вчений віддає перевагу ліричному первню творчості Р. Купчинського перед прозою, що, на його думку, „нині не може на більше претендувати, аніж на літературний факт". Аргументом такого досить категоричного твердження є аналітична праця на основі перевидання роману-трилогії Р. Купчинського Заметіль, що отримала схвалення львівської громадськості. Залучення до огляду раннього періоду творчості письменника біографічних подробиць із його стрілецької епопеї дозволило Т. Сализі зробити висновки принаймні про його ранню творчість: „Талант не зреалізувався на повну потужність, бо Купчинський пішов українськими визвольними фронтами"14. Т. Салига говорить про проблему ревізії оцінок творчості Р. Купчинського як окремої творчої особистості, так і в контексті літератури січового стрілецтва, що їх репрезентувала галицька літературна критика. Як доводить дослідник, „сьогодні можна говорити 3 певністю, що тогочасна критика усіх його заслуг не хотіла бачити"15. Як приклад упередженості, зумовленої конкуренцією часописів та угрупувань і репрезентованих ними естетичних й ідеологічних уподобань, дослідник згадує про маніфест 1927 p. західноукраїнського літературно-мистецького часопису „Літературні вісті”. Він містив приховані, безособові, але полемічно виразні апострофи до представників стрілецького поетичного покоління: „Мета нашого журналу — освободити творчі сили з-під грубого леду застарілих догм і форм, що плаксивим наспівом колискової пісні заколисували наш народ тоді, коли треба було пірвати його до світла й соборного зриву"16.

Критичні праці Т. Салиги висвітлили актуальність подальших літературознавчих окреслень творчості Р. Купчинського, зокрема в ділянці стильової диференціації (стосовно поетики лірики). У цьому вбачаємо такі проблемні напрями: символізм, неоромантизм та імпресіонізм. Перший напрям узвичаївся ще з літературно-критичних відгуків про діяльність „Митуси” і їі символістські маніфести та відповідну поетичну практику в біографії Р. Купчинського (у приналежності його до „Митуси” та впливу В. Бобинського). Таке бачення проявляється від початку літературознавчої рецепції творчості Р. Купчинського в ранніх публікаціях критиків (Є. Пеленський, В. Заїкін, М. Семчишин, Б. Бойчук, Б. Рубчак ін.).

${ }^{13}$ М. Присяжний, Заради найвищого блага, [в:] Тарас Салига, Львів 2003, с. 19.

${ }^{14}$ Т. Салига, Бард украӥнської пісні... і не тільки бард... [Творча сильветка Р. Купчинського], [в:] „Муза і меч”: національний рух у фольклорних та літературних джерелах, Львів 2005 , c. 10.

${ }^{15}$ Там само, с. 29.

${ }^{16}$ Т. Салига, Від „Молодої Музи” до символізму та інших напрямків, Зазнач. джерело, c. 39-40. 
Однак поетичний матеріал, що фігурує в згаданих критичних працях, далеко не повний, здебільшого аналізувалися відомі, найбільш яскраві твори. Чимало поезій Р. Купчинського залишилося „за кадром”, зокрема такі виразні з погляду поетикальних цінностей, як Сльота. Загалом комплексний підхід у дослідженні лірики Р. Купчинського вже має певні здобутки, тоді як проза, ліро-епос, публіцистика, мемуаристика в такому ракурсі ще не досліджувалися. Про це $\epsilon$ лише окремі згадки. Наприклад, роман-трилогія Заметіль була осмислена з огляду на іiі місце в літературному процесі Галичини (Т. Салига), особливостей структури (Д. Гамаш), жанрового синтезу із документалістичними формами (М. Хороб, О. Щербина), мовно-стилістичних особливостей (Л. Бублейник).

Ліро-епос Р. Купчинського як об’єкт літературознавчих розвідок репрезентований незначною кількістю публікацій. Поема Великий день цікавить 3 жанрового та стильового боку (В. Качкан, Т. Салига). Історіософський вимір поеми бачимо в студії М. Козачок, морально-етичний - I. Приходько. Поему Скороnад, зокрема іiі жанрову своєрідність, зв'язок з іншими сатиричними творами аналізують I. Іванець, I. Кедриа, Р. Коритко, Т. Салига, І. Приходько. У зв’язку зі складністю, що постає перед дослідниками, дати жанрове визначення творів ліро-епосу Р. Купчинського, виникає проблема їх сприйняття та питання виявлення ознак родо-видового синтезу, тобто ліро-епічних структур із власне епічними та драматичними структурними елементами, наприклад, існує думка, що поема Скоропад у жанровій структурі має ознаки повісті, драми, гротеску, тоді як у пісенній ліриці домінує документалістика та хронографічність.

Спостерігаємо посилення уваги до життєпису Р. Купчинського. Проблема деталізації біографії письменника об’єднує праці В. Качкана, Т. Салиги, М. Ільницького, хоча жодна із них не генералізує зазначену проблему. Однак важливим видається не тільки реконструювання повної хронології життя і творчості Р. Купчинського, але й відновлення причинно-наслідкових зв'язків між літературним і особистим життям. У цьому напрямку було зроблено перші кроки щодо систематизації бібліографічних матеріалів та формування масиву біографічно-інформативних публікацій про Р. Купчинського в довідкових та інших виданнях, що усталюють присутність Р. Купчинського в українському літературному дискурсі. Цінними здобутками в царині життєпису є відновлення генеалогії роду Купчинських, фактографічні дані літературно-громадської діяльності письменника в міжвоєнному літературному Львові, зокрема його участь у ТОПІЖ, літературній дискусії на сторінках „На зустрічі” тощо. Окремі фрагменти біографії Р. Купчинського містять праці, присвячені іншим діячам української літератури та національно-визвольного руху. Матеріали галицьких часописів 1920-1930-х рр., діаспорні статті впливали на аксіологічні установки творчої особистості Р. Купчинського, його потуги в тому чи тому літературному роді, його „ніші” в ієрархії літературної продукції. Певною мірою продовженням оцінок Б.-І. Антонича та С. Гординського, які бачили Р. Купчинського в лавах середньостатичних поетів, пісні яких годились лише для оплакування свіжих могил, $є$ судження М. Ільницького про літературний процес Галичини першої половини XX століття. Дослідник зауважує, що з позицією Б.-І. Антонича, С. Гординського погодилися, мабуть, не всі, оскільки стрілецька поезія, зокрема пісня, пережила друге відродження наприкінці 80-х — на початку 90-х pp., у час відновлення української державності. Естетичні оцінки М. Ільницького творчої постаті Р. Купчинського на галицькому українському небосхилі міжвоєнної доби мають поступальний характер. Якщо 1993 року в статті 
Стрілецьька поезія він стримано назвав Р. Купчинського прихильником символізму, який не розкрив на повну силу свого таланту через те, що не зміг оновити й поглибити своє захоплення символізмом ${ }^{17}$, то в розвідці 1999 року, присвяченій українській літературній панорамі міжвоєнного періоду, мікросильвета Р. Купчинського сповнена значно тепліших барв. Тут вже є акцент на непроминальності його творів, що „не тільки стали сторінкою української поезії 20-х років, а й увійшли в народну свідомість" 18 .

Р. Купчинський як історична постать, творча особистість перебуває в силовому полі інших наукових напрямів, насамперед історичної, фольклористичної та пресознавчої галузей. Такі дослідження служать важливим доповненням до біографії Р. Купчинського з Першої світової війни, ЗУНР, українськопольської війни та періоду журналістської діяльності в галицький періодиці міжвоєнного часу. Питання історії стрілецьких пісень Р. Купчинського, їх фольклоризму, фольклоризації та місця в контексті військового фольклору Першої світової війни і в сучасній народній уснопоетичній традиції розглядають у фольклористичних працях.

Отже, висвітлені праці демонструють науково-критичне ставлення до творчої особистості Р. Купчинського. На основі їх аналізу можемо вичленувати три етапи наукового вивчення: міжвоєнний період на сторінках галицької періодики, повоєнний етап в діаспорних студіях та розвідки останніх десятиліть сучасних українських літературознавців, між якими існує методологічний зв'язок та єдина джерельна база. У них вирізнено Р. Купчинського з численного потоку письменницьких персоналій як непересічного автора, заангажованого в національно-визвольний процес.

${ }_{17}^{17}$ М. Ільницький, Стрілецька поезія, [в:] Історія украӥнської літератури XX cm., у 2 кн., за ред. В. Г. Дончика, Київ 1993, кн.1: 1910-1930-ті рр., с. 279.

${ }_{18}$ М. Ільницький, „Між двома війнами...”, Західноукраӥнська та еміграчійна поезія 20-30-х років ХХ століття, [в:] „Дзвін”, 1999, № 4, с. 116-117. 